\title{
Efficacy of Anhydrous Copper Sulphate as a Solid Dehydrant in Tissue Processing Procedure
}

\author{
Casilda Sushanthi. L1, Herald Justin Sherlin², Gifrina Jayaraj ${ }^{3}$, Kanchi Ravi Don ${ }^{4}$, Archana Santhanam ${ }^{5}$ \\ 1, 2, 3, 4, 5 Department of Oral and Maxillofacial Pathology, Saveetha Dental \\ College and Hospitals, Saveetha Institute of Medical and Technical \\ Sciences, Saveetha University, Chennai, Tamil Nadu, India.
}

\section{ABSTRACT}

\section{BACKGROUND}

Tissue processing in histotechnique is an important procedure after specimen collection involving three main procedures namely, dehydration using alcohol, clearing using xylene, and infiltration by paraffin wax. Isopropyl alcohol, the widely used dehydrating agent is toxic and when exposed to heated isopropyl alcohol fumes, it leads to numerous health hazards. Anhydrous copper sulphate is less toxic than isopropyl alcohol and requires less amount of exposure to the chemicals. The aim of the study was to investigate the dehydrating potential of anhydrous $\mathrm{CuSO}_{4}$ as an isopropyl alcohol substitute.

\section{METHODS}

A descriptive study of forty paired soft tissue specimens were obtained from the Department of Oral Pathology and Microbiology and were subjected to routine histopathological tissue processing with isopropyl alcohol and anhydrous $\mathrm{CuSO}_{4}$ as dehydrating agents. Histomorphological criteria namely nuclear staining, cytoplasmic staining, artefacts, and background staining were evaluated and the scores were tabulated, and statistical analysis was done using SPSS version 20 by IBM.

\section{RESULTS}

Our study results showed that $40 \%$ of alcohol dehydrated tissue samples had better nuclear staining than tissue samples dehydrated by anhydrous copper sulphate and $15 \%$ of alcohol dehydrated tissue samples had better cytoplasmic staining than tissues dehydrated by Anhydrous $\mathrm{CuSO}_{4}$. Background staining of more than $20 \%$ was seen in anhydrous $\mathrm{CuSO}_{4}$ dehydrated tissue specimens than alcohol dehydrated tissue specimens. Artefacts were seen in similar ratios in both alcohol (80\%) and anhydrous copper sulphate $(75 \%)$ dehydrated tissue specimens.

\section{CONCLUSIONS}

Anhydrous $\mathrm{CuSO}_{4}$ has superior dehydrating properties than isopropyl alcohol which lead to over-dehydration of the tissue specimens. Further studies are required to validate the findings.

\section{KEY WORDS}

Isopropyl Alcohol, Anhydrous Copper Sulphate, Toxicity, Histopathology Alternatives
Corresponding Author: Dr. Herald J Sherlin. Department of Oral and Maxillofacial Pathology, Saveetha Dental College and Hospitals, Saveetha Institute of Medical and Technical Sciences, Chennai-77,

Tamil Nadu, India.

E-mail: heraldsherlin@gmail.com

DOI: 10.14260/jemds/2020/657

How to Cite This Article:

Sushanthi LC, Sherlin HJ, Jayaraj G, et al. Efficacy of anhydrous copper sulphate as a solid dehydrant in tissue processing procedure. J Evolution Med Dent Sci 2020;9(40):3004-3008, $10.14260 /$ jemds/2020/657

Submission 01-07-2020,

Peer Review 27-08-2020,

Acceptance 04-09-2020,

Published 05-10-2020.

Copyright (C) 2020 Casilda Sushanthi, et al. This is an open access article distributed under Creative Commons Attribution License [Attribution 4.0 International (CC BY 4.0)] 


\section{BACKGROUND}

Tissue processing in histotechnique is an important procedure after specimen collection. Tissue processing is a step by step procedure that exposes the biopsy specimen to various chemical agents in a sequence. It involves 3 main procedures namely, dehydration using alcohol, clearing using xylene and infiltration by paraffin wax. These procedures are mandatory in histopathological laboratories in order to prepare the tissue specimens for sectioning. ${ }^{1}$ Dehydration is the most imperative step in diagnostic pathology. An ideal dehydrant should remove unbound water and aqueous fixatives from the tissue compartment. After dehydration, the tissue specimens are subjected to a clearing process which removes alcohol from the tissue specimens. This enables easy penetration of paraffin wax into the tissue. Infiltration by paraffin wax provides support to the tissue specimens and is embedded in paraffin wax.

Isopropyl alcohol has a chemical formula of $\mathrm{C}_{3} \mathrm{H}_{8} \mathrm{O}$. It easily dissolves in water, ethyl alcohol and other reagents because of its low acidic nature. Isopropyl alcohol is also less toxic when compared with Xylene. ${ }^{2}$ Dehydration is important because paraffin wax is not miscible with water which might interfere with sectioning of the tissue specimen and impact the diagnosis. Isopropyl alcohol is a widely used tissue dehydrant due to its ease of use and economic viability. ${ }^{3}$ Isopropyl alcohol enters the human body through fumes or vapours during handling of the chemical reagent in tissue processing method, which can be toxic in long duration. Alcohol vapours that emerge after heating of alcohol rapidly enters the human body. Its absorption is also rapid and it directly reaches the brain via arterial blood. Though not many literatures have focused on inhalation of alcohol vapours, long term exposure to alcohol vapours affects the human body and should not be neglected. ${ }^{4}$

Apart from isopropyl alcohol, butanol, dioxane, ethanol, dimethoxy propane, methanol, phenol polyethylene glycols and tetrahydrofuran can be used as dehydrating agents. ${ }^{5}$ The dry method of dehydration by substituting Isopropyl alcohol by Anhydrous copper sulphate is less toxic and also reduces the duration of exposure to the chemicals. Anhydrous Copper Sulphate are the inorganic compounds with the chemical formula $\mathrm{CuSO}_{4}$ and are solid crystals in nature. Anhydrous $\mathrm{CuSO}_{4}$ does not require heat to initiate the dehydration process and also frequent changes done for liquid chemical agents are also not required which marginally reduces the exposure to chemical agents. With this principle, copper sulphate crystals are used for dry dehydration method, with no pre-existing literature, to the best of our knowledge, on use of anhydrous copper sulphate as a dry dehydrant in tissue processing procedures.

Copper sulphate crystals absorb moisture from the environment when exposed to air. The reaction between Anhydrous $\mathrm{CuSO}_{4}$ and water is usually used as a test for alcohol. When Anhydrous $\mathrm{CuSO}_{4}$ crystals are mixed with water, they absorb water and change colour from pale blue to dark blue. Thus, one molecule of anhydrous $\mathrm{CuSO}_{4}$ will contain 5 molecules of water. Quality check for alcohols used in tissue processing can be done to detect the presence of water after each cycle of tissue processing. This enables to maintain the quality of histopathological specimens and also prolongs the alcohol shelf life. Anhydrous $\mathrm{CuSO}_{4}$ removes water content from alcohol. ${ }^{6}$ As a result of increasing concerns about the potential carcinogenicity of the alcohols, implementing less toxic solutions in routine histopathology is necessary. The main purpose of the study was to investigate the efficacy of anhydrous copper sulphate as alcohol substitute in routine histopathological procedure.

\section{METHODS}

This is a descriptive study carried out in the Department of Oral and Maxillofacial Pathology, Saveetha Dental College and Hospitals, Chennai. The study was approved by the Institutional Review Board. Forty paired soft tissue specimens were selected based on the previous studies reported on routine tissue processing and the selected soft tissue specimens were prepared for routine histopathological evaluation using isopropyl alcohol (Group II) (20 tissue samples) and anhydrous copper sulphate (Group I) (20 tissue samples) as dehydrating agents. Each group was categorized into 4 subgroups based on the different types of tissues such as muscle, adipose tissue, salivary gland and oral mucosa with 5 tissue specimens in each subgroup.

\section{Histopathology Processing}

The department has a pre-established in-house tissue processing protocol. The reagents for histopathological processing were manufactured by MERCK. Anhydrous copper sulphate crystals by Akshar Chemicals were bought from an online commercial market. Copper sulphate crystals were finely powdered to avoid damage to the tissue. A layer of powdered $\mathrm{CuSO}_{4}$ (25 grams) was placed at the bottom of a clean airtight container. The formalin fixed tissue (Group I) was washed in water, excess water was pat dried with tissue paper and was placed on a layer of $\mathrm{CuSO}_{4}$ (25 grams) in an airtight container and another layer ( 25 grams) of powdered $\mathrm{CuSO}_{4}$ was added covering the tissues completely. The container is closed tightly and placed in a dry area for a duration of 4 hours. After dry dehydration, the tissues were subjected to clearing in Xylene for 30 minutes of 2 changes respectively at 50 degree Celsius followed by impregnation in paraffin wax for one overnight at 50 degree Celsius and embedding in paraffin wax.

Simultaneous tissue processing was done using Isopropyl alcohol and Acetone as dehydrating agents (Group II). The impregnated tissues were embedded and tissue sections of 3 micron were made using semi-automated tissue rotary microtome by Leica (RM - 2245), Germany. Tissue sections were later stained with haematoxylin and eosin stain to assess tissue morphology.

Evaluation of tissue Sections: The paired tissue sections were evaluated by 2 independent Oral Pathologists blinded to the type of dehydration process. The slides were evaluated according to the histomorphological criteria's such as nuclear staining, cytoplasmic staining, background staining and artifacts The histomorphological criteria were graded with a score of 1 - poor; 2 - fair; 3 - good; 4 - excellent for nuclear staining and cytoplasmic staining, 0 - nil; 1 - mild; 2 - moderate; 3 - severe for background staining and 0 - no; 1 - yes for artefacts. 
In mucosal tissue samples, $60 \%$ of alcohol dehydrated tissue samples showed excellent nuclear staining against $40 \%$ of $\mathrm{CuSO}_{4}$ dehydrated tissue samples with good nuclear staining ( $\mathrm{p}=0.007$, significant), good cytoplasmic staining was seen in $80 \%$ of alcohol dehydrated tissue samples and fair cytoplasmic staining was seen in $100 \%$ of $\mathrm{CuSO}_{4}$ dehydrated tissue samples ( $p=0.004$ significant), which is statistically significant. Background staining was appreciated in $60 \%$ of $\mathrm{CuSO}_{4}$ dehydrated tissue samples against $80 \%$ of alcohol dehydrated tissue samples with no background staining $(\mathrm{p}=$ 0.221), which is statistically not significant. Artefacts were seen in $80 \%$ of alcohol dehydrated tissue samples and in 100 $\%$ of $\mathrm{CuSO}_{4}$ dehydrated tissue samples with a statistically not significant value of $\mathrm{p}=0.317$ (Table 5).

\begin{tabular}{|c|c|c|c|c|c|c|c|}
\hline Tissue & Parameters & $\begin{array}{c}\text { Types of } \\
\text { Processing }\end{array}$ & Poor & Fair & Good & Excellent & $\begin{array}{c}p \\
\text { Value }\end{array}$ \\
\hline \multirow{5}{*}{$\begin{array}{c}\text { Adipose } \\
\text { Tissue }\end{array}$} & $\begin{array}{l}\text { Nuclear } \\
\text { Staining }\end{array}$ & $\begin{array}{c}\text { Routine } \\
\text { Processing } \\
\text { CuSO }_{4} \\
\text { Processing }\end{array}$ & $0 \%$ & $0 \%$ & $80 \%$ & $20 \%$ & 0.180 \\
\hline & $\begin{array}{l}\text { Cytoplasmic } \\
\text { Staining }\end{array}$ & $\begin{array}{c}\text { Routine } \\
\text { Processing } \mathrm{CuSO}_{4} \\
\text { Processing }\end{array}$ & $0 \%$ & $80 \%$ & $20 \%$ & $40 \%$ & 0.189 \\
\hline & \multirow{2}{*}{$\begin{array}{l}\text { Background } \\
\text { Staining }\end{array}$} & $\begin{array}{l}\text { Routine } \\
\text { Processing } \\
\mathrm{CuSO}_{4}\end{array}$ & $\begin{array}{c}\mathrm{Nil} \\
80 \%\end{array}$ & $\begin{array}{l}\text { Mild } \\
20 \%\end{array}$ & $\begin{array}{c}\text { Moderate } \\
0 \%\end{array}$ & $\begin{array}{c}\text { Severe } \\
0 \%\end{array}$ & \multirow[t]{2}{*}{0.204} \\
\hline & & Processing & $20 \%$ & $80 \%$ & $0 \%$ & $0 \%$ & \\
\hline & Artifacts & $\begin{array}{c}\text { Routine } \\
\text { Processing } \\
\mathrm{CuSO}_{4} \\
\text { Processing }\end{array}$ & $\begin{array}{r}\text { Pres } \\
80\end{array}$ & $\begin{array}{l}\text { ent } \\
\%\end{array}$ & & $\begin{array}{l}\text { sent } \\
0 \%\end{array}$ & 0.221 \\
\hline $\begin{array}{r}\text { Tabl } \\
\text { S } \\
\text { Dehy }\end{array}$ & $\begin{array}{c}\text { Compar } \\
\text { ten bet } \\
\text { ted Tiss } \\
\text { was }\end{array}$ & of Adeq & $\mathrm{cu}$ & 10 & Signi & $\begin{array}{l}\text { dipos } \\
\text { rous } \\
\text { P Val } \\
\text { int }\end{array}$ & $\begin{array}{l}\text { sue } \\
4 \\
0.05\end{array}$ \\
\hline
\end{tabular}

\begin{tabular}{|c|c|c|c|c|c|c|c|}
\hline Tissue & Parameters & $\begin{array}{c}\text { Types of } \\
\text { Processing }\end{array}$ & Poor & Fair & Good & Excellent & $\begin{array}{c}\mathbf{p} \\
\text { Value }\end{array}$ \\
\hline \multirow{4}{*}{ Mucosa } & $\begin{array}{l}\text { Nuclear } \\
\text { Staining }\end{array}$ & $\begin{array}{c}\text { Routine } \\
\text { Processing } \\
\mathrm{CuSO}_{4} \\
\text { Processing }\end{array}$ & $0 \%$ & $60 \%$ & $40 \%$ & $\begin{array}{c}60 \% \\
0 \%\end{array}$ & $0.007 *$ \\
\hline & $\begin{array}{l}\text { Cytoplasmic } \\
\text { Staining }\end{array}$ & $\begin{array}{c}\text { Routine } \\
\text { Processing } \text { CuSO }_{4} \\
\text { Processing }\end{array}$ & $\begin{array}{l}0 \% \\
0 \%\end{array}$ & $\begin{array}{l}20 \% \\
100 \%\end{array}$ & $\begin{array}{c}80 \% \\
0 \%\end{array}$ & $\begin{array}{l}0 \% \\
0 \%\end{array}$ & $0.004^{*}$ \\
\hline & $\begin{array}{l}\text { Background } \\
\text { Staining }\end{array}$ & $\begin{array}{c}\text { Routine } \\
\text { Processing } \\
\text { CuSO }_{4} \\
\text { Processing }\end{array}$ & $\begin{array}{c}\text { Nil } \\
80 \% \\
40 \%\end{array}$ & $\begin{array}{l}\text { Mild } \\
20 \% \\
60 \%\end{array}$ & $\begin{array}{c}\text { Moderate } \\
0 \% \\
0 \%\end{array}$ & $\begin{array}{c}\text { Severe } \\
0 \% \\
0 \%\end{array}$ & 0.221 \\
\hline & Artifacts & $\begin{array}{c}\text { Routine } \\
\text { Processing } \\
\mathrm{CuSO}_{4} \\
\text { Processing }\end{array}$ & \multicolumn{2}{|c|}{$\begin{array}{c}\text { Present } \\
80 \%\end{array}$} & & $\begin{array}{l}\text { bsent } \\
0 \% \\
0 \%\end{array}$ & 0.317 \\
\hline $\begin{array}{r}\text { Table } \\
\text { Sp } \\
\text { Dehyc }\end{array}$ & $\begin{array}{l}\text { Comparis } \\
\text { men betw } \\
\text { ted Tissu } \\
\text { was Co }\end{array}$ & $\begin{array}{l}\text { of Adequc } \\
\text { Alcohol } \\
\text { ecimens. } \\
\text { dered to } b\end{array}$ & $\begin{array}{l}\text { of } \\
\text { hyd } \\
\text { rusk }\end{array}$ & $\begin{array}{l}\text { hydra } \\
\text { ted an } \\
\text { Walli } \\
\text { ically }\end{array}$ & $\begin{array}{l}\text { Ition in } N \\
\text { Id Anhyd } \\
\text { is Anova } \\
\text { Signific }\end{array}$ & $\begin{array}{l}\text { Mucosal T } \\
\text { drous CuS } \\
\text { P Value } \\
\text { ant. }\end{array}$ & $\begin{array}{l}\text { Tissue } \\
\mathrm{O}_{4} \\
<0.05\end{array}$ \\
\hline
\end{tabular}

\section{DISCUSSION}

Isopropyl alcohol is a cost effective and easily available alternative to ethyl alcohol that is being used in histopathological lab procedures from the mid-20 th century. The present study is a novel study with no pre-existing literature on usage of Anhydrous copper sulphate as Alcohol substitute in tissue processing procedure. Twenty matched tissue specimens from 4 different tissue types were selected to assess Anhydrous $\mathrm{CuSO}_{4}$ as alcohol substitute. Tissue specimens dehydrated by Alcohol showed better nuclear staining than tissue specimens dehydrated by $\mathrm{CuSO}_{4}$. As far as cytoplasmic staining was concerned, tissue specimens dehydrated by Alcohol showed superior results than tissue specimens dehydrated by anhydrous $\mathrm{CuSO}_{4}$. Majority of the tissue specimens dehydrated by anhydrous $\mathrm{CuSO}_{4}$ had background staining compared to alcohol dehydrated tissue specimens. Artefacts were equally seen in tissue specimens dehydrated by both alcohol and anhydrous $\mathrm{CuSO}_{4}$.

The finding of our study is in accordance with the literature by Viktorov et al who stated that Isopropyl alcohol when used as a dehydrating agent in tissue processing procedure has excellent dehydrating properties.(2) Downside of isopropyl alcohol usage includes its toxicity on the human body. Isopropyl alcohol when ingested is absorbed rapidly by $80 \%$ within 30 minutes causes GIT irritation and individuals exposed to it might experience nausea, abdominal pain and vomiting. ${ }^{7}$ Histopathology technicians and oral pathologists are frequently exposed to isopropyl alcohol vapours during handling of tissue specimens in tissue processing procedure. Contemplating the health of the histopathology technicians and oral pathologists and also regarding the increasing concerns about the potential carcinogenicity of alcohols, it is necessary to implement less toxic solutions in routine histopathology.

Copper sulphate salt is created by treating cupric acid with sulphuric acid, resulting in large bright blue coloured crystals containing five water molecules. Anhydrous copper sulphate is a result of loss of water molecules when copper sulphate is exposed to heat. ${ }^{8}$ The alternating changing property of copper sulphate from anhydrous form to hydrous form was applied in dehydration of tissue specimens in histopathology procedures. When tissue specimens were subjected to dehydration in anhydrous copper sulphate, repeated changes of the chemical agent was not required unlike dehydration in alcohols. This reduces the consecutive exposure to alcohol fumes during tissue processing.

Anhydrous copper sulphate as a dry dehydrant is a first of its kind study in histopathology procedures. With its principle of absorbing moisture from the environment, it was used to evaluate the dehydrating accuracy in tissue specimens of histopathological biopsies. Anhydrous copper sulphate did not yield better results than alcohol. This could be due to the extensive dehydrating capacity of the Anhydrous $\mathrm{CuSO}_{4}$ as the tissue specimens were subjected to anhydrous copper sulphate for a longer duration of 4 hours. In future, depending upon the tissue types, the duration of exposure of the tissue specimens to anhydrous copper sulphate should be altered to achieve the expected outcome.

The authors acknowledge the presence of study limitations namely lesser sample size and selection of only four different tissue types. More tissue types must be selected to evaluate the anhydrous $\mathrm{CuSO}_{4}$ accuracy as a dehydrant at various anatomical sites. Colour deposition on the tissues were seen though it did not hinder the evaluation of histomorphologic criteria. Another limitation includes longer duration of tissue specimen exposure to anhydrous $\mathrm{CuSO}_{4}$ which over-dehydrated the tissue specimen resulting in splitting of tissues during sectioning. Although the comparison between alcohol dehydration and Anhydrous copper sulphate dehydration showed superior results in alcohol dehydrated tissue specimens, it is proved that anhydrous $\mathrm{CuSO}_{4}$ has extensive dehydrating properties. Duration of tissue specimens to anhydrous $\mathrm{CuSO}_{4}$ should be addressed. 


\section{CONCLUSIONS}

The present study proves that anhydrous $\mathrm{CuSO}_{4}$ in powdered form has extensive dehydrating property which led to overdehydration of the tissue specimens. Anhydrous $\mathrm{CuSO}_{4}$ is a cost effective, less toxic and easily available alternative to the traditional Isopropyl alcohol. Substituting isopropyl alcohol with less toxic chemical agents will be a breakthrough in providing a favourable histopathological laboratory environment for histopathology technicians and oral pathologists.

Financial or Other Competing Interests: None.

\section{REFERENCES}

[1] Karnam S, Girish HC, Murgod S, et al. Rapid tissue processing technique: a novel method using methyl salicylate. J Oral Maxillofac Pathol 2018;22(3):443.
[2] Viktorov IV, Proshin SS. Use of isopropyl alcohol in histological assays: dehydration of tissue, enbessing into paraffin, and processing of paraffin sections. Bull Exp Biol Med 2003;136(1):105-6.

[3] Bancroft JD, Gamble M. Theory and practice of histological techniques. $6^{\text {th }}$ edn. Churchill Livingstone 2008: p. 9.

[4] MacLean RR, Valentine GW, Jatlow PI, et al. Inhalation of alcohol vapor: measurement and implications. Alcohol Clin Exp Res 2017;41(2):238-50.

[5] Processing - Tissue sampling, processing and staining. https://tissuesampling.weebly.com/processing.html

[6] Rao S, Masilamani S, Sundaram S, et al. Quality measures in pre-analytical phase of tissue processing: understanding its value in histopathology. J Clin Diagn Res 2016;10(1):EC07-11.

[7] Ashurst JV, Nappe TM. Isopropanol toxicity. In: StatPearls. Treasure Island (FL): StatPearls Publishing 2019.

[8] NCBI Resource Coordinators. Database resources of the National center for biotechnology information. Nucleic Acids Research 2017;45(D1):D12-7. 